Portland State University

PDXScholar

Environmental Science and Management

Faculty Publications and Presentations

9-12-2015

\title{
Diurnal and Seasonal Variations of NO, NO2 and PM2.5 Mass as a Function of Traffic Volumes Alongside an Urban Arterial
}

Christine M. Kendrick

Portland State University

Peter Koonce

Bureau of Transportation, City of Portland

Linda A. George

Portland State University, georgel@pdx.edu

Follow this and additional works at: https://pdxscholar.library.pdx.edu/esm_fac

Part of the Environmental Indicators and Impact Assessment Commons, Environmental Monitoring Commons, and the Urban Studies and Planning Commons Let us know how access to this document benefits you.

\section{Citation Details}

Kendrick, C.M., Koonce, P., George, L.A., Diurnal and seasonal variations of NO, NO2 and PM2.5 mass as a function of traffic volumes alongside an urban arterial, Atmospheric Environment (2015), doi: 10.1016/ j.atmosenv.2015.09.019

This Post-Print is brought to you for free and open access. It has been accepted for inclusion in Environmental Science and Management Faculty Publications and Presentations by an authorized administrator of PDXScholar. Please contact us if we can make this document more accessible: pdxscholar@pdx.edu. 
Diurnal and seasonal variations of $\mathrm{NO}, \mathrm{NO}_{2}$ and $\mathrm{PM}_{2.5}$ mass as a function of traffic volumes alongside an urban arterial

Christine M. Kendrick ${ }^{\mathrm{a}}$, Peter Koonce ${ }^{\mathrm{b}}$, Linda A. George ${ }^{\mathrm{a} *}$

${ }^{\text {a }}$ School of the Environment

Department of Environmental Science and Management

Portland State University SRTC 218

1719 SW $10^{\text {th }}$ Avenue

Portland, OR 97201

Email: kendricc@pdx.edu

$$
\text { georgeL@pdx.edu }
$$

${ }^{\mathrm{b}}$ Portland Bureau of Transportation

City of Portland

1120 SW $5^{\text {th }}$ Avenue, Room 800

Portland, OR 97204

Email: Peter.Koonce@portlandoregon.gov

Phone: 503-823-5382

*Corresponding Author

Email: georgeL@pdx.edu

Phone:503-725-3861 


\begin{abstract}
Urban arterial corridors are landscapes that give rise to short and long-term exposures to transportation-related pollution. With high traffic volumes and a wide mix of road users, urban arterial environments are important targets for improved exposure assessment to traffic-related pollution. A common method to estimate exposure is to use traffic volumes as a proxy. The study presented here analyzes a unique yearlong dataset of simultaneous roadside air quality and traffic observations for a U.S. arterial to assess the reliability of using traffic volumes as a proxy for traffic-related exposure. Results show how the relationships of traffic volumes with NO and $\mathrm{NO}_{2}$ vary not only by time of day and season but also by time aggregation. At short-term aggregations (15 minutes) nitrogen oxides were found to have a significant linear relationship with traffic volumes during morning hours for all seasons although variability was still high $\left(\mathrm{r}^{2}=\right.$ $\left.0.1-0.45 \mathrm{NO}, \mathrm{r}^{2}=0.14-0.27 \mathrm{NO}_{2}\right)$, and little to no relationship during evening periods $\left(\mathrm{r}^{2}<0.01-\right.$ $0.03 \mathrm{NO}, \mathrm{r}^{2}<0.01-0.05 \mathrm{NO}_{2}$ ). Comparisons with coarse annual results validate the use of traffic volumes to estimate annual exposure concentrations for morning periods $\left(\mathrm{r}^{2}=0.89 \mathrm{NO}, \mathrm{r}^{2}=0.87\right.$ $\left.\mathrm{NO}_{2}\right)$ and evening $\mathrm{NO}_{2}\left(\mathrm{r}^{2}=0.46\right)$. Traffic volumes are a weak or poor predictor for annual evening NO $\left(r^{2}=-0.09\right)$ and short-term 15 minute aggregations. Seasonal and diurnal characterizations show that roadside $\mathrm{PM}_{2.5}$ (mass) measurements do not have a relationship with local traffic volumes, leading us to conclude that $\mathrm{PM}_{2.5}$ mass is more tied to regional sources and meteorological conditions. As epidemiology and personal exposure assessment research aims to study health impacts and pollutant levels encountered by pedestrians, bicyclists, those waiting for transit, and other road users, these results show when traffic volumes alone can be a reliable proxy for exposure and when this approach is not warranted.
\end{abstract}

Keywords: Urban, arterial, roadside, $\mathrm{PM}_{2.5}$, nitrogen oxides, exposure assessment

\title{
1. Introduction
}

Transportation-related emissions are a significant component of poor air quality exposures within urban areas. Increasing urbanization worldwide (United Nations 2014) and growth in high density development (Schneider and Woodcock, 2008) will both lead to more people who reside, work, attend school, and commute within a near-road environment. More than four-fifths of the United States population currently resides in metropolitan areas and from 2000 to 2010 population growth rates for metropolitan areas were greater than the national rate (U.S. Census Bureau 2012). Elevated concentrations of traffic-related pollution such as nitric oxide (NO), nitrogen dioxide $\left(\mathrm{NO}_{2}\right)$, and particle number concentrations (PNC) surrounding major roadways has been documented (Karner et al., 2010; Rao et al., 2014; Zhou and Levy, 2007). Adverse respiratory and cardiovascular effects for populations living within this near roadway environment have been shown through epidemiology and toxicology (Brugge et al., 2007; Health Effects Institute, 2010; Kim et al., 2008). Short-term exposures as experienced by drivers, vehicle occupants, or pedestrians are also associated with short-term morbidity and 
negative health responses (McCreanor et al., 2007; Peters et al., 2013, 2004).

The United States Environmental Protection Agency (U.S. EPA), in recognition of the heterogeneous pattern of traffic-related pollution and health impacts, has made the one hour $\mathrm{NO}_{2}$ National Ambient Air Quality Standard more stringent and mandated roadside monitoring of $\mathrm{NO}_{2}$ in large population centers (CFR, 2010). This new roadway monitoring network is primarily sited near major highways and will also include measurements of $\mathrm{PM}_{2.5}$ mass and $\mathrm{CO}$ (Watkins and Baldauf, 2012). Major urban arterial roadways represent $10 \%$ of total U.S. road mileage, but account for $48 \%$ of vehicle miles traveled (US DOT, 1998). Urban arterial systems have high traffic volumes, but unlike highways, accommodate a high compositional mix of road users such as those waiting for transit, pedestrians, and bicyclists. A variety of land uses including residential, school, park, or commercial are located directly at the road edge in these transportation microenvironments. Close proximity to traffic results in higher exposure concentrations to traffic-related pollution for all road users (Kaur et al., 2007; Kendrick et al., 2011; Thai et al., 2008). There is also potential for increased uptake of traffic-related pollution for bicyclists and pedestrians due to increased respiration rates or longer travel times (McNabola et al. 2008; Kaur et al. 2007; Bigazzi et al. 2014). The urban arterial microenvironment is an important feature of cities and a key location for increased exposures to traffic-related pollution but remains an under-measured microenvironment.

To our knowledge, the only near road air quality studies using a long-term curbside station have been conducted outside of North America and primarily within European Union countries with different fuel use and vehicle fleets than U.S. cities. Near-road air quality research in the U.S has provided critical data about the spatial extent of traffic-related pollution surrounding highways, emission factors under real-world driving conditions, and the contribution of in-car exposure to total exposure using mobile measurements made within the roadway (Cho et al., 2009; Clements et al., 2009; Fruin et al., 2008; Kimbrough et al., 2013; Richmond-Bryant et al., 2009; Zhang et al., 2004; Zhu et al., 2004). This study uses long-term curbside monitoring (1 year) to assess the magnitude and temporal characteristics of roadside traffic-related pollution alongside a heavily-trafficked arterial that accommodates pedestrians, transit users, cyclists, schools, businesses, and homes at the road edge of a major arterial in Portland, Oregon. The traffic data collection was facilitated through a partnership with the City of Portland, Portland Bureau of Transportation.

The aim of this project is to use roadside measurements to characterize diurnal and seasonal variations of $\mathrm{NO}, \mathrm{NO}_{2}$, and $\mathrm{PM}_{2.5}$ as a function of traffic volumes. Such characterizations directly improve understanding of ambient surrogates of traffic for the U.S. urban arterial microenvironment. Characterization by time of day and seasons is important as epidemiological studies incorporate time activity patterns within cohort studies to understand exposure beyond annual mean concentrations (Adar and Kaufman, 2007). The promotion of active transportation modes such as bicycling and walking also increases the need for understanding short-term concentrations to improve exposure evaluation for these travel modes 
(de Nazelle et al., 2011; Tiwary et al., 2011). Lastly, our analysis has implications for using traffic volumes as a proxy for transportation-related emissions. For example, land use regression (LUR) typically uses proximity to road type or traffic volumes to estimate exposure (Hoek eal. 2008). As LUR models are developed to predict more temporally resolved exposure estimates and health studies move towards shorter term exposure and impact assessments, the limitations of traffic volumes as a proxy highlighted here are important to note.

\section{Methods}

An air quality monitoring station was established at a high traffic intersection that includes a diverse mix of road users (freight, public transit, pedestrians, cyclists and passenger vehicles) in Portland, Oregon USA (southwest corner of SE Powell Boulevard and SE $26^{\text {th }}$ Avenue, Figure 1). SE Powell Boulevard is a major arterial roadway that runs east/west with peak hourly traffic volumes of 2,800 vehicles and 28,000 Average Annual Daily Traffic (AADT), including $6 \%$ trucks on weekdays.

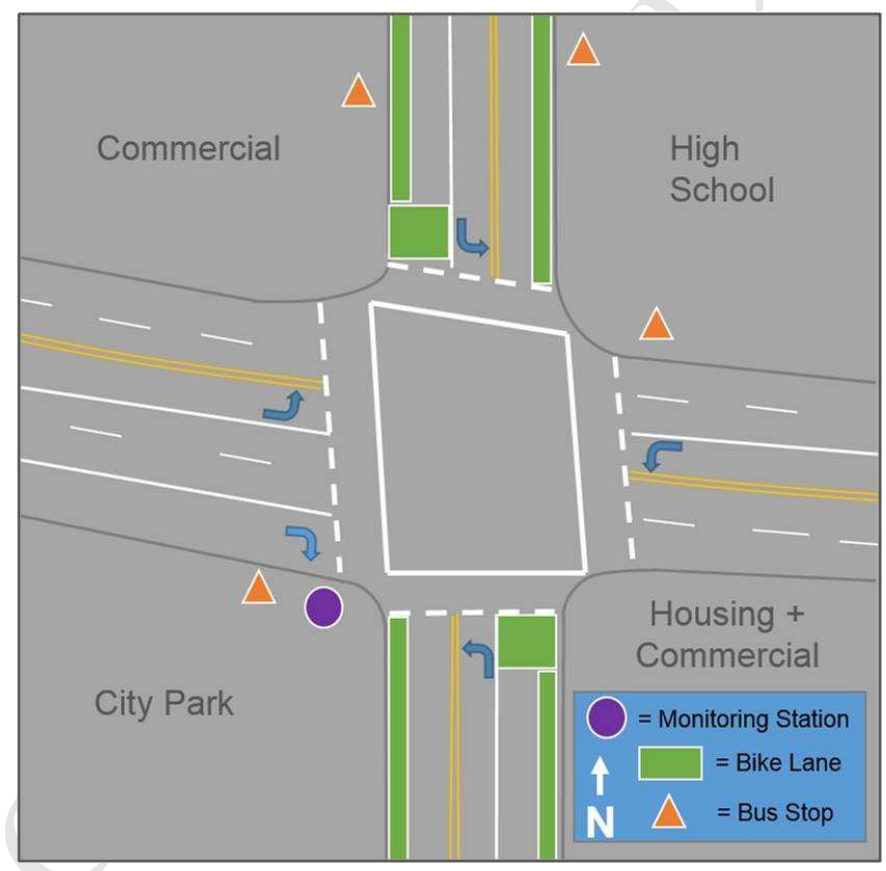

Figure 1 Schematic of study intersection. Air quality station (purple circle) is located on the SW corner of SE Powell Blvd which runs east/west and SE $26^{\text {th }}$ Ave runs north/south

Pedestrian activity through the intersection is high due to the school, housing, a city park, and access to bus stops for major north-south and east-west bus routes. A snapshot traffic survey was conducted by the City of Portland for two hour periods each in the morning (including school start) and evening on one day in February 2012 (PortlandMaps 2014). Total pedestrians crossing the intersection, not including individuals waiting at bus stops, was 225 and 157 for 
morning and evening two hour period. The two hour morning bicycle count for all crossings was 111 bikes and the evening count was 106 bikes. City bicycle data shows summer biking levels to range from 1.8-2.4 times higher than bike counts for the month of February which is cold and wet for the Portland area (Bike Barometer: Hawthorne Bridge 2014).

Traffic volumes in fifteen minute bins for each lane in the intersection were collected using inductive loop detectors and the Sydney Coordinated Adaptive Traffic System (SCATS) infrastructure. SCATS is an adaptive signal system that operates on a $6 \mathrm{~km}$ stretch of Powell Boulevard including the study intersection (Kendrick et al., 2014). $\mathrm{NO}$ and $\mathrm{NO}_{2}$ were monitored using a Teledyne T200 chemiluminescence analyzer and $\mathrm{PM}_{2.5}$ using a TSI DRX DustTrak monitor. Equipment is housed in a pole mounted traffic signal cabinet with a sampling inlet placed $2.5 \mathrm{~m}$ above the sidewalk and connected to the inlet with non-reactive sampling lines. The height of the inlet ensures that intakes are out of reach of disturbance from the street (due to nearby busy bus stop) but still captures road emissions at the street level. Prior to installation, needed lengths of tubing for each instrument were tested to confirm that there was no significant loss in pollutants. Calibration of the NOx analyzer was performed throughout the study period using certified standard gases and calibration of the DustTrak was conducted through factory calibration with zero and flow checks performed on site, with zero checks performed approximately every 14 days.

Additional data collected at the intersection includes wind speed and direction (RM Young 3D Sonic Anemometers Model 81000), temperature and relative humidity (RM Young Probe Model 41382VC). Wind data was also supplemented with measurements from the Oregon Department of Environmental Quality's (DEQ) regional monitoring station. The DEQ site is located $3.4 \mathrm{~km}$ east of the roadside station and $0.09 \mathrm{~km}$ south of Powell Boulevard. Continuous air quality ( $\mathrm{NO}, \mathrm{NO}_{2}, \mathrm{PM}_{2.5}$ ) and meteorology data from this background station is collected, stored and accessed through Horizons database (George et al., 2005). The DEQ site instruments and calibration procedures follow federal monitoring guidelines. All data referred to as "urban background" is from this DEQ station.

Data analysis presented here is based on one year of monitoring including a total of 362 days of NOx and 289 days of $\mathrm{PM}_{2.5}$ measurements at 30-second intervals (January 01, 2013December 31, 2013). Total sampling points for $\mathrm{PM}_{2.5}$ were limited by flow and data storage issues as well as time off-site for factory calibration. For quality assurance/quality control (QA/QC), measurements made outside of each instrument's operating temperature range based on continuous monitoring of the cabinet temperature were excluded from further analysis. Photometers such as the DustTrak can overestimate ambient particulate matter concentrations due to particle composition, density, morphology, and relative humidity due to hygroscopicity. A correction factor of 0.5 was applied to the DustTrak measurements based on a comparison study in Portland between DustTrak and gravimetric measurements of ambient $\mathrm{PM}_{2.5}$ (Zhu et al., 2011). Data presented is aggregated to 15 minutes to allow for direct comparisons with 15 minute binned traffic volumes. Analysis uses measurements only when the wind direction was 
coming from the road. This will be referred to as the road wind direction bin which includes $270^{\circ}$ $(\mathrm{W})$ to $365^{\circ}(\mathrm{N})$ and $0^{\circ}(\mathrm{N})$ to $125^{\circ}(\mathrm{SE})$ in order to capture arterial traffic influences. Data analysis was conducted using $\mathrm{R}$ statistical language and the lattice and quantreg packages ( $\mathrm{R}$ Core Team 2013, Sarkar 2008, Koenker 2015).

\section{Results and Discussion}

\subsection{Traffic and Pollutant Relationships}

Mean, median, $5^{\text {th }}$ and $95^{\text {th }}$ percentile values of roadside $\mathrm{NO}, \mathrm{NO}_{2}, \mathrm{PM}_{2.5}$ and traffic volumes are presented in Table 1 to show distributions of measurements and compare to urban background concentrations. Data is separated by weekdays and weekends. For each pollutant, roadside measurements show elevated peak concentrations $\left(95^{\text {th }}\right.$ percentiles) compared to background levels, demonstrating an increase in measured pollutant levels for the roadside over urban background. Over the entire monitoring period, roadside weekday and weekend means are significantly greater than urban background means for all three pollutants (t-values ranging from 4.4 to 32 , all p-values $<0.01$ using a data subset in which serial correlation has been reduced).

Roadside $\mathrm{NO}_{2}$ and $\mathrm{PM}_{2.5}$ show smaller differences from urban background levels than roadside $\mathrm{NO}$. This is not unexpected for $\mathrm{NO}_{2}$ since the rate of secondary formation of $\mathrm{NO}_{2}$ directly at the roadside would vary depending on mechanical turbulence, dispersion by wind, and existing concentrations of $\mathrm{NO}$, ozone $\left(\mathrm{O}_{3}\right.$, primary oxidant for $\mathrm{NO}$ to $\mathrm{NO}_{2}$ conversion) and other chemical species. Additionally, the urban background site is located within the $300 \mathrm{~m}$ buffer that $\mathrm{NO}$ and $\mathrm{NO}_{2}$ are typically elevated above background concentrations from the major road (Karner et al., 2010). The average $\mathrm{NO} / \mathrm{NO}_{2}$ ratio for the urban background site is 0.7 while the average $\mathrm{NO} / \mathrm{NO}_{2}$ ratio at the roadside site is 1.6 showing a higher proportion of $\mathrm{NO}$ or freshly emitted pollutants as expected directly at a roadside.

Mean weekday and weekend $\mathrm{PM}_{2.5}$ roadside concentrations were found to be significantly higher than background levels by a mean of the differences equal to only $2 \mu \mathrm{g} / \mathrm{m}^{3}$ (weekdays) and $1 \mu \mathrm{g} / \mathrm{m}^{3}$ (weekends). The DustTrak has a resolution of $1 \mu \mathrm{g} / \mathrm{m}^{3}$ so the statistically significant difference is just above or at instrument resolution. Weekend mean and $95^{\text {th }}$ percentile $\mathrm{PM}_{2.5}$ concentration for both the roadside and urban background site are slightly higher than weekdays despite higher traffic volumes on weekdays. Table 1 does not show a strong local signal for roadside $\mathrm{PM}_{2.5}$ measurements compared to urban background. 
Table 1 Roadside and urban background comparisons for weekdays and weekends, spanning Jan 2013- Dec 2014 at 15 minute aggregations.

\begin{tabular}{|c|c|c|c|c|}
\hline \multirow[b]{2}{*}{ Pollutant } & \multicolumn{2}{|c|}{ Weekdays } & \multicolumn{2}{|c|}{ Weekends } \\
\hline & $\begin{array}{c}\text { Roadside } \\
\text { Mean } \\
\text { Median } \\
\left(5^{\text {th }}-95^{\text {th }} \text { Percentiles }\right)\end{array}$ & $\begin{array}{c}\text { Urban Background } \\
\text { Mean } \\
\text { Median } \\
\left.\text { (5 } 5^{\text {th }}-95^{\text {th }} \text { Percentiles }\right)\end{array}$ & $\begin{array}{c}\text { Roadside } \\
\text { Mean } \\
\text { Median } \\
\left(5^{\text {th }}-95^{\text {th }} \text { Percentiles }\right)\end{array}$ & $\begin{array}{c}\text { Urban Background } \\
\text { Mean } \\
\text { Median } \\
\left.\text { (5 } 5^{\text {th }}-95^{\text {th }} \text { Percentiles }\right)\end{array}$ \\
\hline NO (ppb) & $\begin{array}{c}28 \\
20 \\
(1.3-79) \\
\end{array}$ & $\begin{array}{c}9 \\
2 \\
(0.4-45)\end{array}$ & $\begin{array}{c}18 \\
10 \\
(1-59)\end{array}$ & $\begin{array}{c}8 \\
2 \\
(0.4-38) \\
\end{array}$ \\
\hline $\mathrm{NO}_{2}(\mathrm{ppb})$ & $\begin{array}{c}16 \\
15 \\
(5-31)\end{array}$ & $\begin{array}{c}11 \\
9 \\
(3-24)\end{array}$ & $\begin{array}{c}11 \\
10 \\
(4-23)\end{array}$ & $\begin{array}{c}9 \\
7 \\
(2-22) \\
\end{array}$ \\
\hline $\mathrm{PM}_{2.5}\left(\mu \mathrm{g} / \mathrm{m}^{3}\right)$ & $\begin{array}{c}9 \\
6 \\
(0-28)\end{array}$ & $\begin{array}{c}7 \\
5 \\
(2-20)\end{array}$ & $\begin{array}{c}10 \\
5 \\
(0-32)\end{array}$ & $\begin{array}{c}8 \\
5 \\
(2-22)\end{array}$ \\
\hline $\begin{array}{l}\text { Traffic Volumes/ } \\
15 \text { mins }\end{array}$ & $\begin{array}{c}493 \\
554 \\
(65-888) \\
\end{array}$ & & $\begin{array}{c}395 \\
407 \\
(74-735) \\
\end{array}$ & \\
\hline
\end{tabular}

To further investigate the roadway impact, the relationship of each pollutant versus traffic volumes for all weekdays and road wind direction bin is shown in Figure 2. The rest of the data analysis presented will focus on weekdays only when traffic volumes and exposure concentrations are highest and also because weekends show separate diurnal patterns. The median relationship between each pollutant concentration and vehicle volumes binned by fifty is highlighted by triangles in Figure 2. These relationships show increasing $\mathrm{NO}$ and $\mathrm{NO}_{2}$ with increasing traffic volumes and little change in $\mathrm{PM}_{2.5}$ mass as a function of traffic at the intersection. Roadside $\mathrm{NO}$ and $\mathrm{NO}_{2}$ are markers of the increased roadway emissions while roadside $\mathrm{PM}_{2.5}$ mass is not responsive to local traffic volumes. For all three pollutants, variance is high as highlighted in Figure 2. How this variability changes by season and time of day is investigated next using seasonal and diurnal characterizations. 

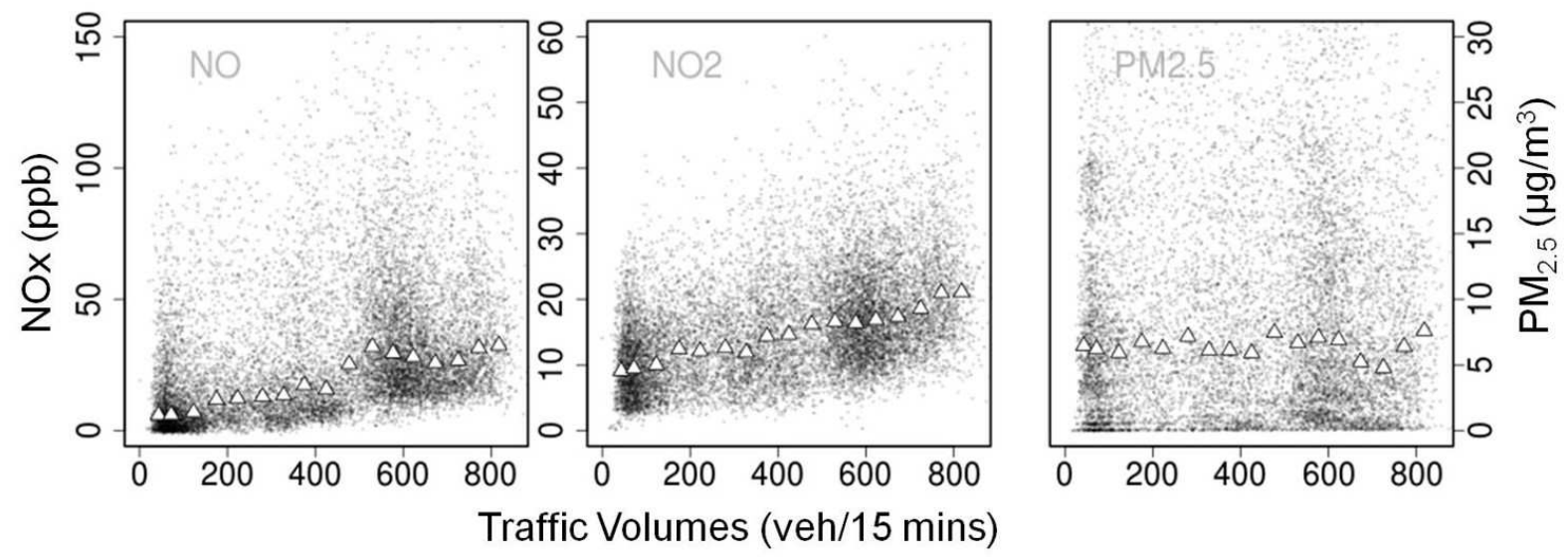

Figure 2 Weekday roadside pollutant measurements versus traffic volumes. White triangles show the median relationship of each pollutant with traffic volume bins of fifty.

\subsection{Weekday, Seasonal and Diurnal Characterization of Roadside Pollutant Concentrations}

Seasonal trends and diurnal patterns of traffic volumes and both roadside and urban background pollutant measurements are presented in Figure 3 with black lines representing the $5^{\text {th }}$ and $95^{\text {th }}$ percentiles and the colored line is the median. Total traffic volumes and peak morning and evening traffic volumes do not change much seasonally for the study intersection (Figure 3a). Daily peak and median concentrations for all three pollutants are greatest in the fall and winter for roadside (Figure 3b, c, e) and urban background measurements (Figure 3g, h, j) showing the potential for higher peak exposures to occur in the fall and winter for urban residents. 

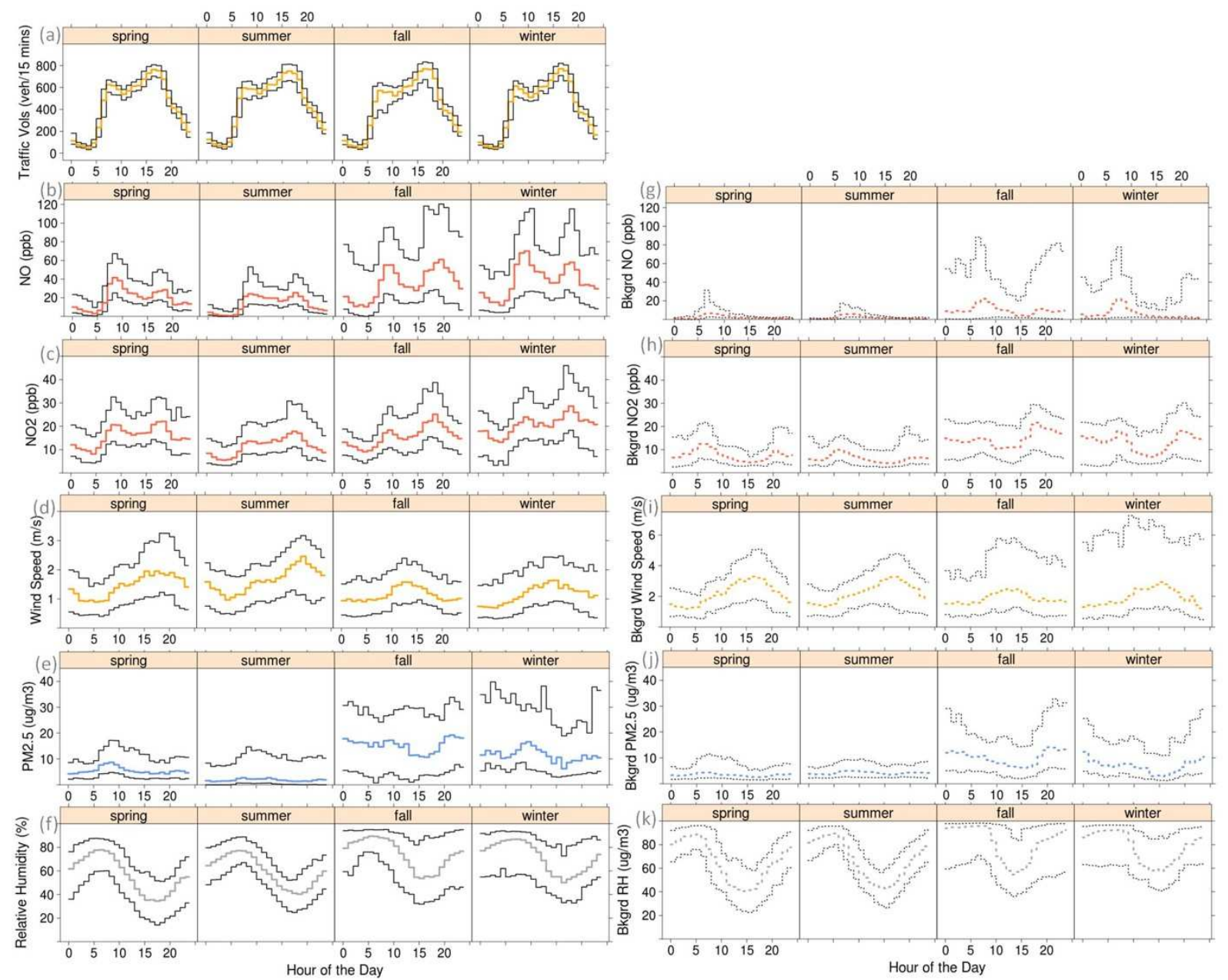

Figure 3 Weekday, seasonal diurnal distributions for (a) traffic volumes, (b-f) roadside NO, $\mathrm{NO}_{2}$, wind speed, $\mathrm{PM}_{2.5}$, and relative humidity, and (g-k) urban background $\mathrm{NO}, \mathrm{NO}_{2}$, wind speed, $\mathbf{P M}_{2.5}$, and relative humidity.

\subsubsection{Diurnal NO and $\mathrm{NO}_{2}$}

Roadside $\mathrm{NO}$ and $\mathrm{NO}_{2}$ have a bi-modal diurnal distribution for weekdays reflecting the morning and evening rush hours (Figure $3 \mathrm{a}, \mathrm{b}, \mathrm{c}$ ). The $\mathrm{NO}$ and $\mathrm{NO}_{2}$ bi-modal pattern shows a seasonal trend. The evening peaks of $\mathrm{NO}$ and $\mathrm{NO}_{2}$ are more pronounced in fall and winter. The fall/winter and spring/summer differences in bi-modal distributions can be attributed to seasonal boundary layer height conditions and subsequent lower median wind speeds in fall and winter, and a change in the diurnal wind pattern by season (Figure 3d). As the height of the boundary layer increases in spring and summer, wind speed increases at a faster rate throughout the day, increasing dispersion. Urban background $\mathrm{NO}$ and $\mathrm{NO}_{2}$ (Figure $3 \mathrm{~g}$ and $3 \mathrm{~h}$ ) show similar seasonal trends with higher concentrations in fall and winter and a more dominant peak in morning with little to no evening peak in spring and summer. 
Diurnal trends documented in other roadside monitoring studies are attributed to a combination of meteorology and changing traffic volumes throughout the year or measurements occur over a small segment of the year so the seasonal variation in diurnal trends is not captured. Summertime roadside measurements made in Raleigh, North Carolina near a highway showed only a morning peak in traffic-related pollutants (NO and $\mathrm{CO}$ ) attributed to variable winds (Baldauf et al., 2008; Thoma et al., 2008). Springtime urban arterial roadside measurements made in Copenhagen, Denmark showed two peaks for NOx, but the afternoon peak was less distinct and attributed to lower afternoon traffic volumes (Wang et al., 2010). Urban arterial roadside measurements made in Athens, Greece over several years showed seasonal, diurnal variation in roadside NO with the highest evening peak occurring in winter attributed to a combination of stable atmospheric conditions and higher traffic volumes compared to other months (Mavroidis and Ilia, 2012). Additionally, Mavroidis and Ilia (2012) showed very little differences in $\mathrm{NO}_{2}$ diurnal trends across seasons with winter concentrations being the lowest.

In contrast, we show distinct seasonal, diurnal differences that are due primarily to meteorology as the diurnal traffic volumes for this study road are uniform throughout the whole year and data presented is for wind directions coming from the road only. The influence of boundary layer height and meteorology is supported by the urban background concentration trends while roadside measurements show higher concentrations and the distinct bi-modal pattern following local traffic volumes for fall and winter. A strong boundary layer height effect on $\mathrm{NO}_{2}$ with highest concentrations in winter despite the lower presence of oxidants is also shown. Urban background $\mathrm{NO}_{2}$ concentrations present this same seasonal pattern. Traffic simulation and emissions modeling for planning and transportation projects typically use evening peak traffic volumes. Usually these models have a target of estimating maximum emission levels; evening peak traffic volumes tend to be greater than morning levels. However, if a transportation project requires estimates of peak pollutant concentrations and not just peak emissions, the results presented here show that morning periods are also important. The morning period could be used as a more consistent input across seasons for exposure concentration estimates depending on the objective of the modeling or exposure assessment project.

\subsubsection{Diurnal $\mathbf{P M}_{2.5}$}

$\mathrm{PM}_{2.5}$ concentrations do not show a bi-modal distribution correlated with traffic (Fig 3e). The lack of this pattern in seasonal, diurnal $\mathrm{PM}_{2.5}$ distributions is consistent with the lack of a strong relationship between local traffic volumes and roadside $\mathrm{PM}_{2.5}$ mass. An increase in the morning can be seen for spring and winter. The median morning increase is $4 \mu \mathrm{g} / \mathrm{m}^{3}$ for spring occurring between 8-9am and $6 \mu \mathrm{g} / \mathrm{m}^{3}$ for winter occurring between 9-10am. These morning increases show some response to increasing traffic volumes, but the response is not consistent throughout the year. Concentrations are highest in fall and winter for both roadside and urban background $\mathrm{PM}_{2.5}$ when boundary layer height is lower (Figure 3j). The diurnal pattern for these seasons is dominated by high relative humidity reflected by the elevated $\mathrm{PM}_{2.5}$ levels in early morning and nighttime which follow the seasonal, diurnal relative humidity distributions (Figure 
$3 \mathrm{f}$ and $3 \mathrm{k}$ ). The cooler temperatures and higher relative humidity increase condensation and coagulation leading to increased $\mathrm{PM}_{2.5}$ (Jamriska et al., 2008). Annual and seasonal, diurnal distributions for measured $\mathrm{PM}_{2.5}$ do not consistently reflect the local traffic volumes well and are most characteristic of meteorological conditions such as relative humidity and boundary layer height also reflected in urban background $\mathrm{PM}_{2.5}$.

Particulate matter is a component of traffic-related emissions but mass measurements do not always capture this influence. Karner et al's (2010) meta-analysis based on over fifteen studies with $\mathrm{PM}_{2.5}$ measurements around roadways found mixed results regarding the spatial distribution of fine particles. Using a background normalization method, $\mathrm{PM}_{2.5}$ was found to have no trend around roadways so was not elevated at the roadside compared to background. However, using an edge of the roadway normalization method, $\mathrm{PM}_{2.5}$ was found to have a gradual decay away from roads. For an area such as Portland, OR that does not have as much diesel traffic as a freeway in California or a European roadway, the increase in $\mathrm{PM}_{2.5}$ mass directly from transportation-related emissions may be too small of a signal above the noise and secondary formation of urban background pollution.

Particles in the $\mathrm{PM}_{2.5}$ range have a variety of anthropogenic sources in urban areas including other primary combustion sources (industry, large-scale cooking, liquid and solid fuel heating), non-road sources (construction equipment, railways), and secondary formation via gas to particle conversions, coagulation and condensation of smaller particles (Monn, 2001). These sources and processes lead to a more spatially homogenous pattern of $\mathrm{PM}_{2.5}$ mass. While $\mathrm{PM}_{2.5}$ mass does not always show the impact of local traffic emissions, other measurements of particulates can. Particle composition has shown to vary spatially near roadways while $\mathrm{PM}_{2.5}$ mass had low spatial variation (Martuzevicius et al., 2004). A review of indoor, outdoor, and personal exposure to particulates found $\mathrm{PM}_{2.5}$ spatial variation to be much smaller compared to particle number concentrations and larger size fractions (Monn et al. 2001). Our results and the variability in $\mathrm{PM}_{2.5}$ mass responses to traffic across studies suggests that measurements of $\mathrm{PM}_{2.5}$ mass as a proxy to assess the impact of roadway pollution may need location-specific validation.

\subsection{Estimating Roadside NOx as a Function of Traffic Volumes}

Measured roadside $\mathrm{NO}$ and $\mathrm{NO}_{2}$ is responsive to local traffic volumes, but with distinct seasonal and diurnal trends on the fifteen minute time scale. If traffic volumes are used as a proxy in exposure assessment focused on shorter time scales such as the time a pedestrian or bicyclist spends in the roadside microenvironment, traffic volumes alone may not correlate with roadside exposure concentrations. Quantile regression for the median is used to assess roadside $\mathrm{NOx}$ as a function of traffic volumes for short-term aggregations (15 minutes) for morning periods (5-10am) and evening periods (3-8pm) for each season. Time periods were chosen based on the previous diurnal, seasonal analysis to help control for meteorological differences and traffic peaks in order to assess traffic volumes alone as a predictor variable. 
NOx and traffic volume measurements showed autocorrelation with high correlation coefficients for each value and the value at a lag of 1 . In order to address this serial correlation while still allowing the use of high resolution measurements, three data points were randomly sampled from each morning and evening period per day. This sampling method reduced autocorrelation between $\mathrm{NO}$ and $\mathrm{NO}_{\text {lag1 }}$ from 0.9 to $0.52, \mathrm{NO}_{2}$ and $\mathrm{NO}_{2 \operatorname{lag} 1}$ from 0.71 to 0.41 , and traffic volumes and traffic volumes lag1 from 0.96 to 0.38 (total number of sample points used to build the models reduced from 13,739 to 1,197). Figure 4 shows the median regression relationships of $\mathrm{NO}_{2}$ as a function of traffic volumes for morning and evening periods by season. Table 2 shows the following values for $\mathrm{NO}$ and $\mathrm{NO}_{2}$ models built using both the randomly selected data subset and all data: model coefficients per 100 vehicles in a 15 minute period, standard errors for the coefficients per 100 vehicles, and $r^{2}$ values. Quantile regression was used due to the right skewed nature of the data and because quantile regression can capture when a change in the independent variable exerts both a change in mean and variance in the dependent variable so heteroskedasticity is not a major concern (Davino et al., 2013).
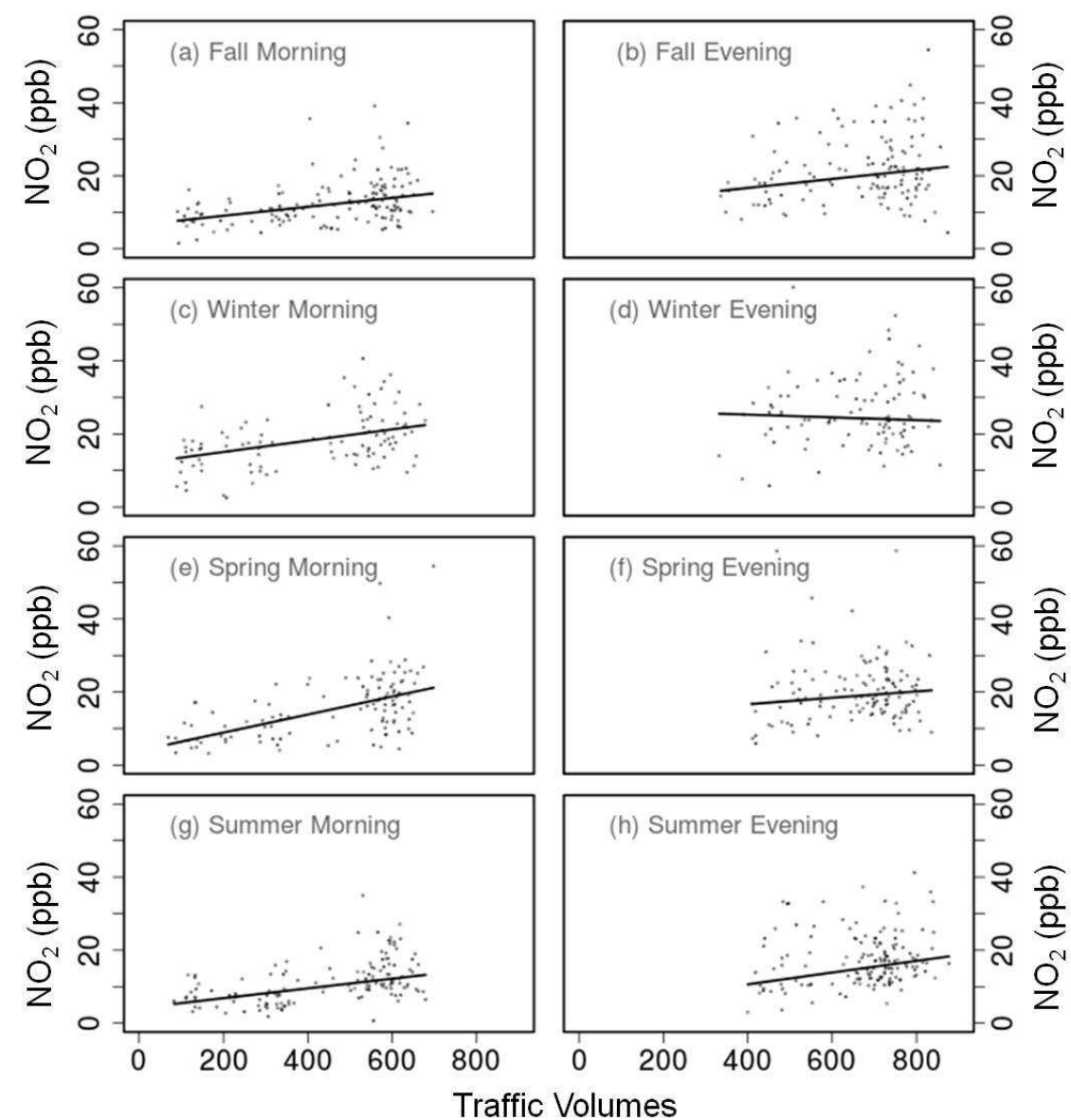

Traffic Volumes

Figure 4 Median regression relationships of roadside $\mathrm{NO}_{2}$ and traffic volumes for morning and evening periods by season. 
Table 2 Median regression model results for roadside NOx as a function of traffic volumes using randomly sampled subset (black) and all serially correlated data points (grey). (**significance at $<0.01$ and *significance at $<0.05$ )

\begin{tabular}{|c|c|c|c|c|c|c|c|}
\hline Season & $\begin{array}{c}\text { Time } \\
\text { Period }\end{array}$ & $\begin{array}{l}\text { Coefficient NO } \\
\text { per } 100 \text { vehicles } \\
\text { per } 15 \text { mins }\end{array}$ & $\begin{array}{l}\text { Standard Error } \\
\text { of Coefficient NO } \\
\text { per } 100 \text { vehicles } \\
\text { per } 15 \text { mins }\end{array}$ & $\begin{array}{c}\text { Adjusted } \\
r^{2}\end{array}$ & $\begin{array}{c}\text { Coefficient } \mathrm{NO}_{2} \\
\text { per } 100 \text { vehicles } \\
\text { per } 15 \text { mins }\end{array}$ & $\begin{array}{l}\text { Standard Error } \\
\text { of Coefficient } \mathrm{NO}_{2} \\
\text { per } 100 \text { vehicle } \\
\text { per } 15 \text { mins }\end{array}$ & $\begin{array}{c}\text { Adjusted } \\
r^{2}\end{array}$ \\
\hline Fall & Morning & $\begin{array}{l}6.3^{* *} \\
(7.9)^{* *}\end{array}$ & $\begin{array}{c}1.4 \\
(0.4)\end{array}$ & $\begin{array}{c}0.1 \\
(0.16)\end{array}$ & $\begin{array}{c}1.2^{\star \star} \\
(1.6)^{\star \star}\end{array}$ & $\begin{array}{c}0.2 \\
(0.1)\end{array}$ & $\begin{array}{c}0.14 \\
(0.24)\end{array}$ \\
\hline Winter & Morning & $\begin{array}{c}9.4^{\star \star} \\
(11.2)^{\star \star *}\end{array}$ & $\begin{array}{c}1.4 \\
(0.7)\end{array}$ & $\begin{array}{c}0.14 \\
(0.24)\end{array}$ & $\begin{array}{c}1.5^{\star \star} \\
(1.9)^{\star \star}\end{array}$ & $\begin{array}{c}0.4 \\
(0.2)\end{array}$ & $\begin{array}{c}0.17 \\
(0.26)\end{array}$ \\
\hline Spring & Morning & $\begin{array}{l}6.3^{* *} \\
(6.7)^{* *}\end{array}$ & $\begin{array}{c}0.8 \\
(0.3)\end{array}$ & $\begin{array}{c}0.41 \\
(0.43)\end{array}$ & $\begin{array}{l}2.5^{\star \star} \\
(2.3)^{* \star}\end{array}$ & $\begin{array}{c}0.3 \\
(0.2)\end{array}$ & $\begin{array}{c}0.27 \\
(0.28)\end{array}$ \\
\hline Summer & Morning & $\begin{array}{l}4.6^{\star \star} \\
(4.4)^{* \star}\end{array}$ & $\begin{array}{l}(0.4) \\
(0.2)\end{array}$ & $\begin{array}{l}(0.45) \\
(0.37)\end{array}$ & $\begin{array}{l}1.3^{* *} \\
(1.6)^{* *}\end{array}$ & $\begin{array}{c}0.3 \\
(0.1)\end{array}$ & $\begin{array}{c}0.25 \\
(0.23)\end{array}$ \\
\hline Fall & Evening & $\begin{array}{l}-1.3 \\
(-1.6)\end{array}$ & $\begin{array}{c}2.5 \\
(1.1)\end{array}$ & $\begin{array}{l}<0.001 \\
(0.005)\end{array}$ & $\begin{array}{l}1.2^{*} \\
(0.9)\end{array}$ & $\begin{array}{c}0.6 \\
(0.2)\end{array}$ & $\begin{array}{c}0.05 \\
(0.03)\end{array}$ \\
\hline Winter & Evening & $\begin{array}{l}-0.04 \\
(0.09)\end{array}$ & $\begin{array}{c}2.6 \\
(1.3)\end{array}$ & $\begin{array}{c}0.002 \\
(0.001)\end{array}$ & $\begin{array}{c}-0.4 \\
(-0.08)\end{array}$ & $\begin{array}{c}0.8 \\
(0.4)\end{array}$ & $\begin{array}{c}0.05 \\
(0.03)\end{array}$ \\
\hline Spring & Evening & $\begin{array}{c}2.1 \\
(2.2)^{* * *}\end{array}$ & $\begin{array}{c}1.1 \\
(0.5)\end{array}$ & $\begin{array}{c}0.03 \\
(0.04)\end{array}$ & $\begin{array}{c}0.9 \\
(0.9)^{\star *}\end{array}$ & $\begin{array}{l}(0.8) \\
(0.3)\end{array}$ & $\begin{array}{l}0.007 \\
(0.02)\end{array}$ \\
\hline Summer & Evening & $\begin{array}{c}2.1^{*} \\
(2.9)^{* *}\end{array}$ & $\begin{array}{c}0.8 \\
(0.3)\end{array}$ & $\begin{array}{c}0.02 \\
(0.07)\end{array}$ & $\begin{array}{c}1.6^{*} \\
(1.9)^{* *}\end{array}$ & $\begin{array}{c}0.7 \\
(0.2)\end{array}$ & $\begin{array}{c}0.03 \\
(0.05)\end{array}$ \\
\hline
\end{tabular}

To determine if any significant changes occurred in the model coefficients built using the full dataset versus the models built with the randomly sampled subset, coefficient values plus or minus two standard errors were compared for all models. These comparisons showed the error ranges overlapped for all models demonstrating no significant change in model coefficient estimates. Randomly selecting points within our time periods and seasons to reduce autocorrelation maintains the relationships found using all data. A change in significance is seen for spring evening $\mathrm{NO}$ and $\mathrm{NO}_{2}$ models using all data versus the subset, but coefficient values plus or minus two standard errors still overlap for these models. Morning periods for all four seasons show a significant linear relationship (p-values $<0.01$ ) between traffic volumes and NO and $\mathrm{NO}_{2}$. Boundary layer height is low in the morning for all four seasons creating similar meteorological conditions. As traffic volumes increase throughout the morning and boundary layer height increases as well, a positive linear relationship is seen for traffic volumes and NO and $\mathrm{NO}_{2}$ on a fifteen minute scale. As meteorology introduces higher variability in the evening due to a changing boundary layer and more variable winds, the linear relationship of traffic volumes explains little to none of the variance in roadside 15 minute median NOx for this later time period ( $\mathrm{r}^{2}$ range from $<0.001$ to 0.05$)$.

A linear relationship between NOx and traffic volumes was found for free-flow conditions only based on one month of roadside pollutant and hourly traffic measurements in Leicester, UK (Agus et al., 2007). The linear relationship broke down during unstable and congested traffic flow conditions with occupancy $>10 \%$ (Agus et al., 2007). Results presented here show that the linear relationship even at short-term aggregations holds true past free-flow 
conditions and throughout the congested morning traffic period. We attribute the breakdown in the linear relationship to changing meteorological and dispersion conditions.

While short-term NOx and traffic volume models were significant for all morning periods, variance explained ranged from 0.1 to 0.45 . Figure 5 shows the relationship of traffic volumes and $\mathrm{NO}_{2}$ for morning and evening periods at a coarser aggregation using traffic volume bins of 50 vehicles and data across the entire year. Table 3 shows the annual regression values for $\mathrm{NO}$ and $\mathrm{NO}_{2}$. There is still no significant effect of traffic volumes on annual NO for the evening period. Using binned annual data, variance explained by traffic volumes increases to 0.89 (NO morning), $0.87\left(\mathrm{NO}_{2}\right.$ morning) and 0.46 ( $\mathrm{NO}_{2}$ evening). Summarized over one year, the seasonal and some meteorological variability are averaged out and traffic volumes are a better predictor of annually averaged roadside NOx. Even at a larger aggregation, the evening time period remains more variable compared to mornings. To our knowledge, the data presented is from the only long-term arterial roadside air quality monitoring station in the U.S., but measurements from additional intersections would improve the robustness and application of the relationships found here.

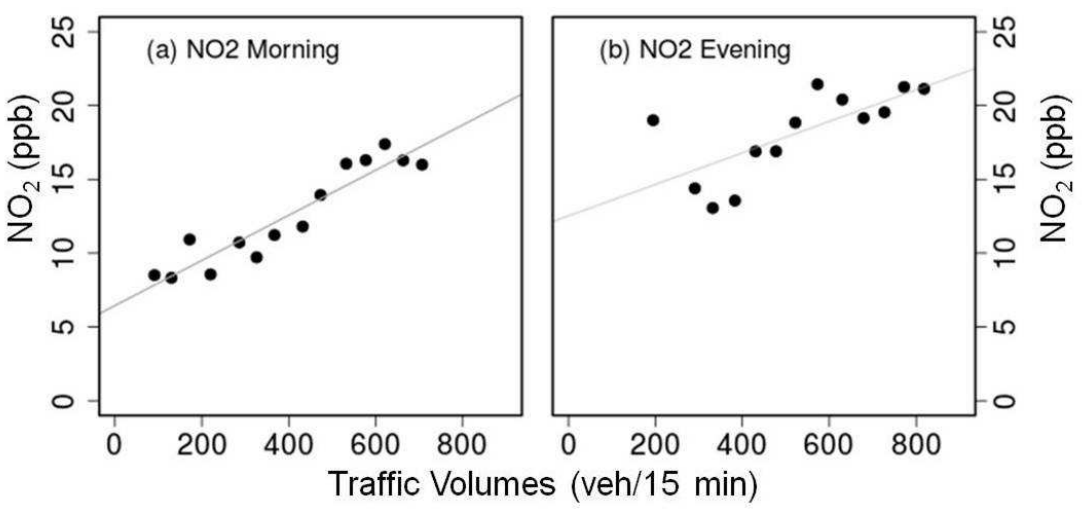

Figure 5 Median roadside $\mathrm{NO}_{2}$ as a function of traffic volumes binned by 50 vehicles across the entire year.

Table 3 Regression results for median annual $\mathrm{NO}$ and $\mathrm{NO}_{2}$ as a function of traffic volumes

\begin{tabular}{|l|l|c|c|c|c|c|c|}
\hline & $\begin{array}{c}\text { Time } \\
\text { Period }\end{array}$ & $\begin{array}{c}\text { Coefficient NO } \\
\text { per } 100 \text { vehicles } \\
\text { per } 15 \text { mins }\end{array}$ & $\begin{array}{c}\text { Standard Error } \\
\text { of Coefficient NO } \\
\text { per } 100 \text { vehicles } \\
\text { per } 15 \text { mins }\end{array}$ & $\begin{array}{c}\text { Adjusted } \\
r^{2}\end{array}$ & $\begin{array}{c}\text { Coefficient NO } \\
\text { per } 100 \text { vehicles } \\
\text { per } 15 \text { mins }\end{array}$ & $\begin{array}{c}\text { Standard Error } \\
\text { of Coefificient } \mathrm{NO}_{2} \\
\text { per } 100 \text { vehicle } \\
\text { per } 15 \text { mins }\end{array}$ & $\begin{array}{c}\text { Adjusted } \\
r^{2}\end{array}$ \\
\hline Annual & Morning & $6.3^{* *}$ & 0.6 & 0.89 & $1.5^{* *}$ & 0.2 & 0.87 \\
\hline Annual & Evening & -0.2 & 1.4 & -0.09 & $1.1^{* *}$ & 0.3 & 0.46 \\
\hline
\end{tabular}




\section{Conclusion}

In this study, we characterized pollutant levels of an urban arterial roadside environment in a mid-sized U.S. city over the course of a year. Urban arterial roadside environments are under-sampled in the U.S. but have potential to produce high exposures due to the mix of road users and close proximity of urban residents. Roadside monitoring for a variety of roadway types including arterials is well established in European countries, though with different fleet mixes, fuel, vehicle and air quality standards. Such research has helped document long-term trends and important characteristics of traffic-related pollutants but has not focused on analysis of shortterm changes as a function of traffic volume, time of day, and season (Bigi and Harrison, 2010; Carslaw, 2005; Mavroidis and Ilia, 2012). Here we extend the understanding of temporal variability of $\mathrm{NO}$ and $\mathrm{NO}_{2}$ by showing how the relationships with traffic volumes change temporally and we provide model coefficients (Table 3) that are applicable to exposure assessment in North America.

Direct evaluations with local traffic volumes showed $\mathrm{NO}$ and $\mathrm{NO}_{2}$ are significantly affected by traffic volumes and $\mathrm{PM}_{2.5}$ mass is not responsive to traffic volumes at this intersection. $\mathrm{PM}_{2.5}$ mass appears to be more tied to regional sources. Seasonal and diurnal characterization of $\mathrm{NO}$ and $\mathrm{NO}_{2}$ showed morning peaks to be consistent throughout all seasons, while a bi-modal distribution was most prominent in fall and winter. The consistent diurnal traffic volume trends allowed for the large impact of seasonal boundary layer height to be evident. Highest exposures would occur in fall and winter when boundary layer height conditions reduce dilution. Other measures of particulate matter may be needed to capture the increased health risk due to primary combustion particles. This is an important consideration as the U.S. EPA adds PM mass measurements to the roadway monitoring network. Identification of the type of environments that are more locally or regionally dominated by $\mathrm{PM}_{2.5}$ mass could help pinpoint the type of monitoring needed to accurately assess exposure to particulates due to traffic-related emissions. Emissions and dispersion models for the study intersection will be run in the future to allow for comparisons of measured concentrations and model outputs. If modeled $\mathrm{PM}_{2.5}$ mass concentrations are strongly tied to local traffic parameters, the models may be missing important processes related to urban particulate matter formation.

Our study shows the limitations of using traffic volumes alone as a proxy for trafficrelated emissions. Traffic volumes explained little of the variance in roadside NOx for evening time periods across all seasons at 15 minutes aggregations. Morning periods at short-term aggregations showed significant relationships between NOx and traffic volumes for all seasons, but variability was still high. On an annual timescale, the variability in roadside $\mathrm{NO}$ and $\mathrm{NO}_{2}$ due to seasonality and meteorology is reduced and traffic volumes alone are a better predictor of roadside concentrations. Even at this coarser temporal scale, the relationship between traffic volumes and $\mathrm{NO}$ and $\mathrm{NO}_{2}$ in evening periods is not consistent. Using daily averaged data in exposures studies could potentially miss very different patterns of exposure (Bigi and Harrison, 2010). As exposure assessment moves to account for time spent in transportation 
microenvironments, traffic volume data will need to be combined with local meteorology in order to best represent the high variability in roadside pollutant concentrations.

\section{Acknowledgements}

Funding and support for this study were provided by the U.S. EPA Science to Achieve Results (STAR) Fellowship Grant FP917473, NSF DGE Grant 094804, and the Signals, Street Lighting, and ITS Division of the Portland Bureau of Transportation, City of Portland.

\section{References}

Adar, S.D., Kaufman, J.D., 2007. Cardiovascular disease and air pollutants: evaluating and improving epidemiological data implicating traffic exposure. Inhal. Toxicol. 19 Suppl 1, 135-49. doi:10.1080/08958370701496012

Agus, E.L., Young, D.T., Lingard, J.J.N., Smalley, R.J., Tate, J.E., Goodman, P.S., Tomlin, A.S., 2007. Factors influencing particle number concentrations, size distributions and modal parameters at a roof-level and roadside site in Leicester, UK. Sci. Total Environ. 386, 65-82. doi:10.1016/j.scitotenv.2007.07.026

Baldauf, R., Thoma, E., Hays, M., Shores, R., Kinsey, J., Gullett, B., Kimbrough, S., Isakov, V., Long, T., Snow, R., Khlystov, A., Weinstein, J., Che, F.-L., Seila, R., Olson, D., Gilmour, I., Cho, S.-H., Watkins, N., Rowley, P., Bang, J., 2008. Traffic and Meteorological Impacts on Near-Road Air Quality: Summary of Methods and Trends from the Raleigh Near-Road Study. J. Air Waste Manage. Assoc. 58, 865-878. doi:10.3155/10473289.58.7.865

Bigazzi, A.Y., Figliozzi, M. a., 2014. Review of Urban Bicyclists' Intake and Uptake of Traffic-Related Air Pollution. Transp. Rev. 34, 221-245. doi:10.1080/01441647.2014.897772

Bigi, A., Harrison, R.M., 2010. Analysis of the air pollution climate at a central urban background site. Atmos. Environ. 44, 2004-2012. doi:10.1016/j.atmosenv.2010.02.028

Bike Barometer: Portland Hawthorne Bridge [WWW Document], n.d. URL http://portland-hawthorne-bridge.visiotools.com/

Brugge, D., Durant, J.L., Rioux, C., 2007. Near-highway pollutants in motor vehicle exhaust: a review of epidemiologic evidence of cardiac and pulmonary health risks. Environ. Health 6, 23. doi:10.1186/1476069X-6-23

Burea of Technology Services, T.C. of P., GIS, C., n.d. PortlandMaps An Information Service by The City of Portland [WWW Document]. URL https://www.portlandmaps.com/

Carslaw, D.C., 2005. Evidence of an increasing NO/NO emissions ratio from road traffic emissions. Atmos. Environ. 39, 4793-4802. doi:10.1016/j.atmosenv.2005.06.023

CFR, 2010. Primary National Ambient Air Quality Standards for Nitrogen Dioxide; Final Rule 1-65.

Cho, S.-H., Tong, H., McGee, J.K., Baldauf, R.W., Krantz, Q.T., Gilmour, M.I., 2009. Comparative toxicity of sizefractionated airborne particulate matter collected at different distances from an urban highway. Environ. Health Perspect. 117, 1682-9. doi:10.1289/ehp.0900730 
Clements, A.L., Jia, Y., Denbleyker, A., McDonald-Buller, E., Fraser, M.P., Allen, D.T., Collins, D.R., Michel, E., Pudota, J., Sullivan, D., Zhu, Y., 2009. Air pollutant concentrations near three Texas roadways, part II: Chemical characterization and transformation of pollutants. Atmos. Environ. 43, 4523-4534. doi:10.1016/j.atmosenv.2009.06.044

Davino, C., Furno, M., Vistocco, D., 2013. Quantile Regression: Theory and Applications. John Wiley \& Sons, West Sussex, United Kingdom.

De Nazelle, A., Nieuwenhuijsen, M.J., Antó, J.M., Brauer, M., Briggs, D., Braun-Fahrlander, C., Cavill, N., Cooper, A.R., Desqueyroux, H., Fruin, S., Hoek, G., Panis, L.I., Janssen, N., Jerrett, M., Joffe, M., Andersen, Z.J., van Kempen, E., Kingham, S., Kubesch, N., Leyden, K.M., Marshall, J.D., Matamala, J., Mellios, G., Mendez, M., Nassif, H., Ogilvie, D., Peiró, R., Pérez, K., Rabl, A., Ragettli, M., Rodríguez, D., Rojas, D., Ruiz, P., Sallis, J.F., Terwoert, J., Toussaint, J.-F., Tuomisto, J., Zuurbier, M., Lebret, E., 2011. Improving health through policies that promote active travel: a review of evidence to support integrated health impact assessment. Environ. Int. 37, 766-77. doi:10.1016/j.envint.2011.02.003

Fruin, S., Westerdahl, D., Sax, T., Sioutas, C., Fine, P.M., 2008. Measurements and predictors of on-road ultrafine particle concentrations and associated pollutants in Los Angeles. Atmos. Environ. 42, 207-219. doi:10.1016/j.atmosenv.2007.09.057

George, L.A., Parra, J., Sitbon, P., 2005. Horizons- Portland Area Real-Time and Archived Air Quality and Meteorological Data.

Health Effects Institute, 2010. Traffic-Related Air Pollution: A Critical Review of the Literature on Emissions, Exposure, and Health Effects A Special Report of the HEI Panel on the Health Effects of Traffic-Related Air Pollution, Special Report 17, Critical Review.

Hoek, G., Beelen, R., de Hoogh, K., Vienneau, D., Gulliver, J., Fischer, P., Briggs, D., 2008. A review of land-use regression models to assess spatial variation of outdoor air pollution. Atmos. Environ. 42, 7561-7578. doi:10.1016/j.atmosenv.2008.05.057

Jamriska, M., Morawska, L., Mergersen, K., 2008. The effect of temperature and humidity on size segregated traffic exhaust particle emissions. Atmos. Environ. 42, 2369-2382. doi:10.1016/j.atmosenv.2007.12.038

Karner, A. a, Eisinger, D.S., Niemeier, D. a, 2010. Near-roadway air quality: synthesizing the findings from realworld data. Environ. Sci. Technol. 44, 5334-44. doi:10.1021/es100008x

Kaur, S., Nieuwenhuijsen, M.J., Colvile, R.N., 2007. Fine particulate matter and carbon monoxide exposure concentrations in urban street transport microenvironments. Atmos. Environ. 41, 4781-4810. doi:10.1016/j.atmosenv.2007.02.002

Kendrick, C.M., Moore, A., Haire, A., Bigazzi, A., Figliozzi, M., Monsere, C.M., George, L., 2011. Impact of Bicycle Lane Characteristics on Exposure of Bicyclists to Traffic-Related Particulate Matter. Transp. Res. Rec. J. Transp. Res. Board 2247, 24-32. doi:10.3141/2247-04

Kendrick, C.M., Urowsky, D., Rotich, W., Koonce, P., George, L., 2014. Effect of Reducing Maximum Cycle Length on Roadside Air Quality and Travel Times on a Corridor in Portland, OR, in: Transportation Research Board 93rd Annual Meeting Compendium of Papers. pp. 14-2779.

Kim, J.J., Huen, K., Adams, S., Smorodinsky, S., Hoats, A., Malig, B., Lipsett, M., Ostro, B., 2008. Residential traffic and children's respiratory health. Environ. Health Perspect. 116, 1274-9. doi:10.1289/ehp.10735 
Kimbrough, E.S., Baldauf, R.W., Watkins, N., 2013. Seasonal and diurnal analysis of NO2 concentrations from a long-duration study conducted in Las Vegas, Nevada. J. Air Waste Manage. Assoc. 63, 934-942. doi:10.1080/10962247.2013.795919

Martuzevicius, D., Grinshpun, S. a, Reponen, T., Górny, R.L., Shukla, R., Lockey, J., Hu, S., McDonald, R., Biswas, P., Kliucininkas, L., LeMasters, G., 2004. Spatial and temporal variations of PM2.5 concentration and composition throughout an urban area with high freeway density-the Greater Cincinnati study. Atmos. Environ. 38, 1091-1105. doi:10.1016/j.atmosenv.2003.11.015

Mavroidis, I., Ilia, M., 2012. Trends of NOx, NO2 and O3 concentrations at three different types of air quality monitoring stations in Athens, Greece. Atmos. Environ. 63, 135-147. doi:10.1016/j.atmosenv.2012.09.030

McCreanor, J., Cullinan, P., Nieuwenhuijsen, M.J., Stewart-Evans, J., Malliarou, E., Jarup, L., Harrington, R., Svartengren, M., Han, I.-K., Ohman-Strickland, P., Chung, K.F., Zhang, J., 2007. Respiratory Effects of Exposure to Diesel Traffic in Persons with Asthma. N. Engl. J. Med. 357, 2348-2358.

McNabola, a., Broderick, B.M., Gill, L.W., 2008. Relative exposure to fine particulate matter and VOCs between transport microenvironments in Dublin: Personal exposure and uptake. Atmos. Environ. 42, 6496-6512. doi:10.1016/j.atmosenv.2008.04.015

Monn, C., 2001. Exposure assessment of air pollutants : a review on spatial heterogeneity and indoor/outdoor/personal exposure to suspended particulate matter, nitrogen dioxide and ozone. Atmos. Environ. 35, 1-32.

Peters, A., von Klot, S., Heier, M., Trentinaglia, I., Hormann, A., Wichmann, E., Lowel, H., 2004. Exposure to Traffic and the Onset of Myocardial Infarction. N. Engl. J. Med. 351, 1721-1730.

Peters, A., von Klot, S., Mittleman, M. a, Meisinger, C., Hörmann, A., Kuch, B., Wichmann, H.E., 2013. Triggering of acute myocardial infarction by different means of transportation. Eur. J. Prev. Cardiol. 20, 750-8. doi:10.1177/2047487312446672

Rao, M., George, L.A., Rosenstiel, T.N., Shandas, V., Dinno, A., 2014. Assessing the relationship among urban trees, nitrogen dioxide, and respiratory health. Environ. Pollut. 194, 96-104. doi:10.1016/j.envpol.2014.07.011

Richmond-Bryant, J., Hahn, I., Fortune, C.R., Rodes, C.E., Portzer, J.W., Lee, S., Wiener, R.W., Smith, L. a, Wheeler, M., Seagraves, J., Stein, M., Eisner, A.D., Brixey, L. a, Drake-Richman, Z.E., Brouwer, L.H., Ellenson, W.D., Baldauf, R., 2009. The Brooklyn traffic real-time ambient pollutant penetration and environmental dispersion (B-TRAPPED) field study methodology. J. Environ. Monit. 11, 2122-35. doi:10.1039/b907126c

Schneider, a., Woodcock, C.E., 2008. Compact, Dispersed, Fragmented, Extensive? A Comparison of Urban Growth in Twenty-five Global Cities using Remotely Sensed Data, Pattern Metrics and Census Information. Urban Stud. 45, 659-692. doi:10.1177/0042098007087340

Thai, A., McKendry, I., Brauer, M., 2008. Particulate matter exposure along designated bicycle routes in Vancouver, British Columbia. Sci. Total Environ. 405, 26-35. doi:10.1016/j.scitotenv.2008.06.035

Thoma, E., Shores, R., Isakov, V., Baldauf, R., 2008. Characterization of Near-Road Pollutant Gradients Using Path-Integrated Optical Remote Sensing. J. Air Waste Manage. Assoc. 58, 879-890. doi:10.3155/10473289.58.7.879 
Tiwary, A., Robins, A., Namdeo, A., Bell, M., 2011. Air flow and concentration fields at urban road intersections for improved understanding of personal exposure. Environ. Int. 37, 1005-18. doi:10.1016/j.envint.2011.02.006

United, N., 2014. World Urbanization Prospects, the 2014 Revision.

US DOT, 1998. Highwav statistics 1998.

Wang, F., Ketzel, M., Ellermann, T., Wåhlin, P., Jensen, S.S., Fang, D., Massling, A., 2010. Particle number, particle mass and NOx emission factors at a highway and an urban street in Copenhagen. Atmos. Chem. Phys. 10, 2745-2764. doi:10.5194/acp-10-2745-2010

Watkins, N., Baldauf, R., 2012. Near-road NO2 Monitoring Technical Assistance Document.

Wilson, B.S.G., Plane, D.A., Mackun, P.J., Fischetti, T.R., Goworowska, J., Perry, M.J., Hatchard, G.W., 2012. Patterns of Metropolitan and Micropolitan Population Change : 2000 to 2010.

Zhang, K.M., Wexler, A.S., Zhu, Y.F., Hinds, W.C., Sioutas, C., 2004. Evolution of particle number distribution near roadways. Part II: the "Road-to-Ambient" process. Atmos. Environ. 38, 6655-6665. doi:10.1016/j.atmosenv.2004.06.044

Zhou, Y., Levy, J.I., 2007. Factors influencing the spatial extent of mobile source air pollution impacts: a metaanalysis. BMC Public Health 7, 89. doi:10.1186/1471-2458-7-89

Zhu, Y., Hinds, W.C., Shen, S., Sioutas, C., 2004. Seasonal Trends of Concentration and Size Distribution of Ultrafine Particles Near Major Highways in Los Angeles. Aerosol Sci. Technol. 38, 5-13. doi:10.1080/02786820390229156

Zhu, Y., Smith, T.J., Davis, M.E., Levy, J.I., Herrick, R., Jiang, H., 2011. Comparing gravimetric and real-time sampling of $\mathrm{PM}(2.5)$ concentrations inside truck cabins. J. Occup. Environ. Hyg. 8, 662-72. doi:10.1080/15459624.2011.617234 
Table 1 Roadside and urban background comparisons for weekdays and weekends, spanning Jan 2013Dec 2014 at 15 minute aggregations.

\begin{tabular}{|c|c|c|c|c|}
\hline \multirow[b]{2}{*}{ Pollutant } & \multicolumn{2}{|c|}{ Weekdays } & \multicolumn{2}{|c|}{ Weekends } \\
\hline & $\begin{array}{c}\text { Roadside } \\
\text { Mean } \\
\text { Median } \\
\left(5^{\text {th }}-95^{\text {th }} \text { Percentiles }\right)\end{array}$ & $\begin{array}{c}\text { Urban Background } \\
\text { Mean } \\
\text { Median } \\
\left(5^{\text {th }}-95^{\text {th }} \text { Percentiles }\right)\end{array}$ & $\begin{array}{c}\text { Roadside } \\
\text { Mean } \\
\text { Median } \\
\left(5^{\text {th }}-95^{\text {th }} \text { Percentiles }\right)\end{array}$ & $\begin{array}{c}\text { Urban Background } \\
\text { Mean } \\
\text { Median } \\
\left(5^{\text {th }}-95^{\text {th }} \text { Percentiles }\right)\end{array}$ \\
\hline $\begin{array}{c}\text { NO } \\
(p p b)\end{array}$ & $\begin{array}{c}28 \\
20 \\
(1.3-79)\end{array}$ & $\begin{array}{c}9 \\
2 \\
(0.4-45)\end{array}$ & $\begin{array}{c}18 \\
10 \\
(1-59)\end{array}$ & $\begin{array}{c}8 \\
2 \\
(0.4-38)\end{array}$ \\
\hline $\begin{array}{c}\mathrm{NO}_{2} \\
(p p b)\end{array}$ & $\begin{array}{c}16 \\
15 \\
(5-31)\end{array}$ & $\begin{array}{c}11 \\
9 \\
(3-24)\end{array}$ & $\begin{array}{c}11 \\
10 \\
(4-23)\end{array}$ & $\begin{array}{c}9 \\
7 \\
(2-22)\end{array}$ \\
\hline $\begin{array}{c}\mathrm{PM}_{2.5} \\
\left(\mu \mathrm{g} / \mathrm{m}^{3}\right)\end{array}$ & $\begin{array}{c}9 \\
6 \\
(0-28)\end{array}$ & $\begin{array}{c}7 \\
5 \\
(2-20)\end{array}$ & $\begin{array}{c}10 \\
5 \\
(0-32)\end{array}$ & $\begin{array}{c}8 \\
5 \\
(2-22)\end{array}$ \\
\hline $\begin{array}{c}\text { Traffic } \\
\text { Volumes/ } \\
15 \text { mins }\end{array}$ & $\begin{array}{c}493 \\
554 \\
(65-888)\end{array}$ & & $\begin{array}{c}395 \\
407 \\
(74-735)\end{array}$ & \\
\hline
\end{tabular}




\section{ACCEPTED MANUSCRIPT}

Table 2 Median regression model results for roadside NOx as a function of traffic volumes using randomly sampled subset (black) and all serially correlated data pints (grey).

$(* *$ significance at $<0.01$ and $*$ significance at $<0.05)$

\begin{tabular}{|c|c|c|c|c|c|c|c|}
\hline Season & $\begin{array}{c}\text { Time } \\
\text { Period }\end{array}$ & $\begin{array}{l}\text { Coefficient } \\
\text { NO per } 100 \\
\text { vehicles } \\
\text { per } 15 \text { mins }\end{array}$ & $\begin{array}{l}\text { Standard } \\
\text { Error of } \\
\text { Coefficient } \\
\text { NO per } 100 \\
\text { vehicles } \\
\text { per } 15 \text { mins }\end{array}$ & $\begin{array}{c}\text { Adjusted } \\
r^{2}\end{array}$ & $\begin{array}{l}\text { Coefficient } \\
\mathrm{NO}_{2} \text { per } 100 \\
\text { vehicles per } \\
15 \text { mins }\end{array}$ & $\begin{array}{c}\text { Standard } \\
\text { Error of } \\
\text { Coefficient } \\
\mathrm{NO}_{2} \text { per } 100 \\
\text { vehicles per } \\
15 \text { mins }\end{array}$ & $\begin{array}{c}\text { Adjusted } \\
\mathbf{r}^{2}\end{array}$ \\
\hline Fall & Morning & $\begin{array}{l}6.3^{* *} \\
(7.9)^{* *}\end{array}$ & $\begin{array}{c}1.4 \\
(0.4)\end{array}$ & $\begin{array}{c}0.1 \\
(0.16)\end{array}$ & $\begin{array}{c}1.2^{* *} \\
(1.6)^{* *}\end{array}$ & $\begin{array}{c}0.2 \\
(0.1)\end{array}$ & $\begin{array}{c}0.14 \\
(0.24)\end{array}$ \\
\hline Winter & Morning & $\begin{array}{c}9.4^{* *} \\
(11.2)^{* *}\end{array}$ & $\begin{array}{c}1.4 \\
(0.7)\end{array}$ & $\begin{array}{c}0.14 \\
(0.24)\end{array}$ & $\begin{array}{c}1.5^{\star *} \\
(1.9)^{* *}\end{array}$ & $\begin{array}{c}0.4 \\
(0.2)\end{array}$ & $\begin{array}{c}0.17 \\
(0.26)\end{array}$ \\
\hline Spring & Morning & $\begin{array}{c}6.3^{* *} \\
(6.7)^{* *}\end{array}$ & $\begin{array}{c}0.8 \\
(0.3)\end{array}$ & $\begin{array}{c}0.41 \\
(0.43)\end{array}$ & $\begin{array}{l}2.5^{* *} \\
(2.3)^{* *}\end{array}$ & $\begin{array}{c}0.3 \\
(0.2)\end{array}$ & $\begin{array}{c}0.27 \\
(0.28)\end{array}$ \\
\hline Summer & Morning & $\begin{array}{c}4.6^{* *} \\
(4.4)^{* *}\end{array}$ & $\begin{array}{l}(0.4) \\
(0.2)\end{array}$ & $\begin{array}{l}(0.45) \\
(0.37)\end{array}$ & $\begin{array}{c}1.3^{* *} \\
(1.6)^{* *}\end{array}$ & $\begin{array}{c}0.3 \\
(0.1)\end{array}$ & $\begin{array}{c}0.25 \\
(0.23)\end{array}$ \\
\hline Fall & Evening & $\begin{array}{l}-1.3 \\
(-1.6)\end{array}$ & $\begin{array}{c}2.5 \\
(1.1)\end{array}$ & $\begin{array}{l}<0.001 \\
(0.005)\end{array}$ & $\begin{array}{l}1.2^{*} \\
(0.9)\end{array}$ & $\begin{array}{c}0.6 \\
(0.2)\end{array}$ & $\begin{array}{c}0.05 \\
(0.03)\end{array}$ \\
\hline Winter & Evening & $\begin{array}{l}-0.04 \\
(0.09)\end{array}$ & $\begin{array}{c}2.6 \\
(1.3)\end{array}$ & $\begin{array}{c}0.002 \\
(0.001)\end{array}$ & $\begin{array}{c}-0.4 \\
(-0.08)\end{array}$ & $\begin{array}{c}0.8 \\
(0.4)\end{array}$ & $\begin{array}{c}0.05 \\
(0.03)\end{array}$ \\
\hline Spring & Evening & $\begin{array}{c}2.1 \\
(2.2)^{* *}\end{array}$ & $\begin{array}{c}1.1 \\
(0.5)\end{array}$ & $\begin{array}{c}0.03 \\
(0.04)\end{array}$ & $\begin{array}{c}0.9 \\
(0.9)^{* *}\end{array}$ & $\begin{array}{l}(0.8) \\
(0.3)\end{array}$ & $\begin{array}{l}0.007 \\
(0.02)\end{array}$ \\
\hline Summer & Evening & $\begin{array}{c}2.1^{*} \\
(2.9)^{* *}\end{array}$ & $\begin{array}{c}0.8 \\
(0.3)\end{array}$ & $\begin{array}{c}0.02 \\
(0.07)\end{array}$ & $\begin{array}{c}1.6^{*} \\
(1.9)^{* *}\end{array}$ & $\begin{array}{c}0.7 \\
(0.2)\end{array}$ & $\begin{array}{c}0.03 \\
(0.05)\end{array}$ \\
\hline
\end{tabular}

Table 3 Regression results for median annual $\mathrm{NO}$ and $\mathrm{NO}_{2}$ as a function of traffic volumes.

\begin{tabular}{|c|c|c|c|c|c|c|c|}
\hline & $\begin{array}{c}\text { Time } \\
\text { Period }\end{array}$ & $\begin{array}{l}\text { Coefficient } \\
\text { NO per } 100 \\
\text { vehicles } \\
\text { per } 15 \text { mins }\end{array}$ & $\begin{array}{c}\text { Standard } \\
\text { Error of } \\
\text { Coefficient } \\
\text { NO per } 100 \\
\text { vehicles per } \\
15 \text { mins }\end{array}$ & $\begin{array}{c}\text { Adjusted } \\
r^{2}\end{array}$ & $\begin{array}{c}\text { Coefficient } \\
\mathrm{NO}_{2} \text { per } 100 \\
\text { vehicles } \\
\text { per } 15 \text { mins }\end{array}$ & $\begin{array}{c}\text { Standard } \\
\text { Error of } \\
\text { Coefficient } \\
\mathrm{NO}_{2} \text { per } 100 \\
\text { vehicles per } \\
15 \text { mins }\end{array}$ & $\begin{array}{c}\text { Adjusted } \\
r^{2}\end{array}$ \\
\hline Annual & Morning & $6.3^{* *}$ & 0.6 & 0.89 & $1.5^{\star *}$ & 0.2 & 0.87 \\
\hline Annual & Evening & -0.2 & 1.4 & -0.09 & $1.1^{* *}$ & 0.3 & 0.46 \\
\hline
\end{tabular}




\section{Highlights}

Diurnal and seasonal variations of $\mathrm{NO}, \mathrm{NO}_{2}$ and $\mathrm{PM}_{2.5}$ mass as a function of traffic volumes alongside an urban arterial

Christine M. Kendrick, Peter Koonce, Linda A. George

- Arterial air quality has been monitored to assess temporal variability with traffic.

- Traffic volumes have a significant effect on NOx for morning periods in all seasons.

- Traffic volume explains little to no NOx variability in evening periods.

- Roadside $\mathrm{PM}_{2.5}$. mass is not a consistent measure of traffic impact.

- Traffic volumes alone are of limited use to predict short-term roadside exposures. 